\title{
THERMAL ENVIRONMENT OF TABLE GRAPE PACKING HOUSES IN THE SÃO FRANCISCO VALLEY
}

Doi:http://dx.doi.org/10.1590/1809-4430-Eng.Agric.v37n1p35-45/2017

\section{OSVALDO VASCONCELOS ${ }^{1}$, SÍLVIA TURCO ${ }^{2}$, CRISTIANE DACANAL $^{2}$, SIMONE LUZ ${ }^{2}$, SERGIO FREITAS ${ }^{3}$}

\author{
${ }^{1 *}$ Corresponding author. Universidade Federal do Vale do São Francisco-Univasf/ Juazeiro - BA, Brasil. \\ E-mail: eng.osvaldocampelo@hotmail.com
}

\begin{abstract}
The aim of this study was to characterize the thermal environment of the sorting and packing sectors of small, medium and large packing houses in the São Francisco Valley, Northeast of Brazil. Micrometeorological data were monitored every 15 minutes for 20 days during winter 2014 and summer 2015 . The parameters evaluated were air temperature $\left({ }^{\circ} \mathrm{C}\right)$, relative humidity $(\%)$ and radiant thermal load, RTL, $\left(\mathrm{W} / \mathrm{m}^{2}\right)$. External environmental data were obtained from weather stations close to the packing houses. The data obtained show that packing houses minimum and maximum temperatures were reached at $6 \mathrm{am}$ and $3 \mathrm{pm}$, respectively, during winter and summer. Both seasons had air temperatures above $20^{\circ} \mathrm{C}$, relative humidity below $90 \%$ and radiant thermal load above $450 \mathrm{~W} / \mathrm{m}^{2}$. The construction materials that had the highest energy transmissions were the roofs. Metal roofs had the worst thermal conditioning, resulting in maximum internal air temperatures of $32.7^{\circ} \mathrm{C}$ and minimum relative humidity of $40.9 \%$ at $3 \mathrm{pm}$, during summer. According to the results, thermal environments of sorting and packing sectors proved to be inadequate for processing table grapes, mainly during summer. These packing houses should be modified to reach the optimal thermal environment, considering the regional climatic conditions.
\end{abstract}

KEY WORDS: thermal environment, performance, agricultural facilities.

\section{INTRODUCTION}

The qualitative and quantitative postharvest losses are intrinsically related to local environmental conditions and mechanical damage in handling or by the use of inadequate packaging. The external market, to which is intended around $90 \%$ of table grapes produced in the São Francisco Valley (IBGE, 2014), requires fruits with high standard quality, indicated by physicochemical parameters such as soluble solids content, size uniformity, color, absence of damage, berry firmness, among others. The grapes for the domestic market are generally the rejected ones from the selection made for export and are subject to higher perishability, especially for being handled under improper environmental conditions that accelerate the loss of quality. In order to minimize these losses, the right conditions for grape processing require appropriate packaging and storage in refrigerated environments using, therefore, the packing houses structures (RIBEIRO, 2014).

The packing houses of table grapes for exportation have four main sectors - selection and packaging, pre-cooling and storage - which have environments with microclimates and specific design characteristics for the development of activities related to the beneficiation. At the reception of the fruit boxes from the field, there is no conditioning, since it is generally a shaded space for a marquee, but in direct contact with the outer space. The reception is connected to the selection sector, weighing, packaging and pallets formation, environment that must be conditioned with air temperature of $20^{\circ} \mathrm{C}$ and relative humidity at 90\% (SOARES; LEAO, 2009). The pallets are led to the pre-cooling tunnel, to reduce the heat stored inside the packaging and then stored in cold rooms, conditioned in air temperature of $-0.5^{\circ} \mathrm{C}$ and relative humidity at $95 \%$. Finally, the cold room has easy access to the fruits shipping sector, which are transported in trucks with controlled environment (NGCOBO et al., 2013).

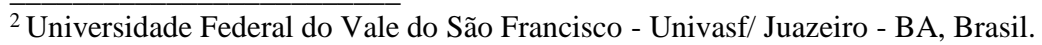

${ }^{3}$ Embrapa/ Petrolina - PE, Brasil.

Received in: 4-20-2016

Accepted in: 9-17-2016
} 
The importance of controlling the thermal environment and the fruits storage time in each of the packing house sectors is related to the losses of postharvest quality. For grape, the lower the time spent between the harvest and the storage in cold room, the lower the qualitative and quantitative quality losses will be (RIBEIRO, 2014).

In order to minimize possible postharvest losses resulting from inadequate environmental conditions and based on the literature recommendations, this study aimed to diagnose the thermal environment of the selection sector of three grape packing houses, located in San Francisco Valley, Tropical semi-arid climate, and to trace relations with the materials of the constructive housing.

\section{MATERIAL AND METHODS}

\section{Description of the study area}

The study was accomplished in three Brazilian fruit farms (packing houses), in the states of Bahia and Pernambuco, in the municipalities of Juazeiro-BA and Petrolina-PE with an altitude between $368 \mathrm{~m}$ and $376 \mathrm{~m}$, respectively. The farms are located in the São Francisco Valley between parallels $8^{\circ}$ and $9^{\circ} \mathrm{S}$, whose climate is semiarid, according to the Koeppen classification, BSwh' type, with an average annual temperature around $26^{\circ} \mathrm{C}$, with minimum air temperature of $24.5^{\circ} \mathrm{C}$ in the winter and maximum air temperature of $28.5^{\circ} \mathrm{C}$ in the summer, and average rainfall of $550 \mathrm{~mm}$ concentrated between November and April (TEXEIRA \& LIMA, 2016).

The architectural study was accomplished in three packing houses (Figure 1): ST (9 17'34''S, $40^{\circ} 29^{\prime} 01^{\prime \prime} \mathrm{O}, 400 \mathrm{~m}$, small size, 6.0 hectares of grape cultivated area), FS (9 $21^{\prime} 33,5^{\prime} \mathrm{S}, 40^{\circ} 37^{\prime} 20,4^{\prime}$ ' $\mathrm{O}, 398 \mathrm{~m}$, medium size, 38.2 hectares of grape cultivated area) and SF ( $9^{\circ} 24^{\prime} 15,5^{\prime \prime} \mathrm{S}, 40^{\circ} 21^{\prime} 08^{\prime \prime} \mathrm{O}$, $381 \mathrm{~m}$, large size, 160.0 hectares of grape cultivated area) for further evaluation of the housing material. Tables 1 and 2 show the dimensions, description of the construction material and ventilation or cooling equipment from each packing house.

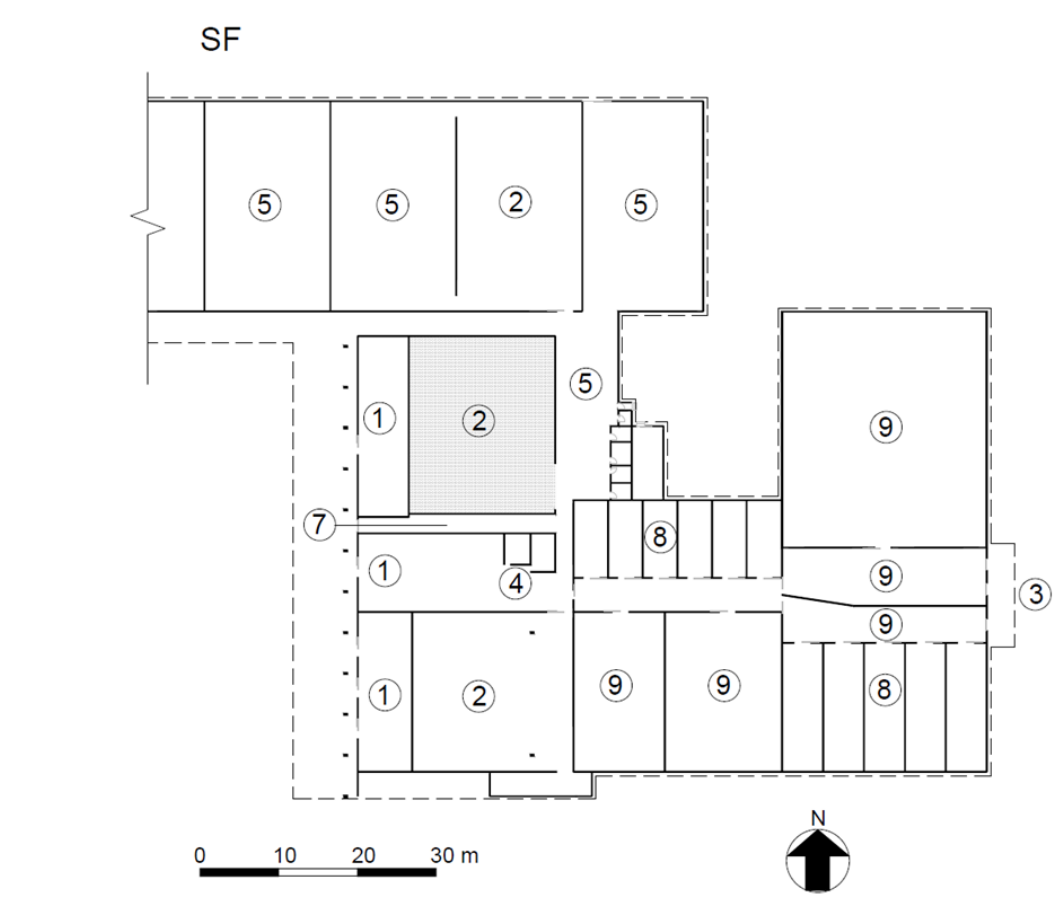
(1) RECEPTION
(4) QUALITY CONTROL
(2) SELECTION, PACKAGING
(5) PACKAGING
(3) SHIPPING
(6) ADMINISTRATION

(7) ACCESS

(8) TUNEL

(9) COOLING ROOM
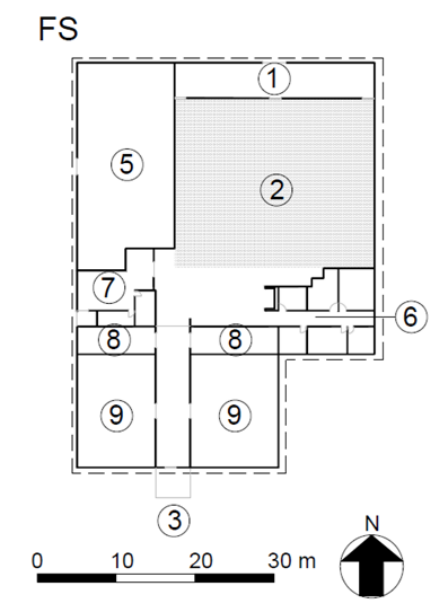

ST

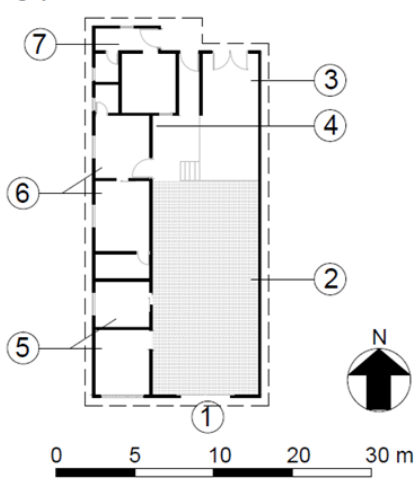

FIGURE 1. Compartmentalization of evaluated ST, FS and SF packing houses plants. Sector 2, in gray, represents the monitored environment. 
TABLE 1. Overall dimensions of the evaluated packing houses.

\begin{tabular}{cccccccc}
\hline & \multicolumn{7}{c}{ Dimensions } \\
\cline { 2 - 7 } $\begin{array}{c}\text { Packing } \\
\text { house }\end{array}$ & Length (m) Width (m) $\begin{array}{c}\text { Celling HighRidge height } \\
(\mathrm{m})\end{array}$ & $\begin{array}{c}\text { Volume of } \\
\text { the selection } \\
\text { sector }\left(\mathrm{m}^{3}\right)\end{array}$ & $\begin{array}{c}\text { Left eaves } \\
\text { façade }(\mathrm{m})\end{array}$ & $\begin{array}{c}\text { Right eaves } \\
\text { façade }(\mathrm{m})\end{array}$ \\
\hline ST & 13.6 & 6.75 & 4.0 & 5.5 & 367.2 & 0.6 & 1.8 \\
FS & 25.4 & 21.6 & 4.5 & 6.0 & 2468.9 & 0.8 & 0.8 \\
SF & 20.35 & 20.5 & 4.5 & 6.0 & 1877.3 & 0.8 & 0.8 \\
\hline
\end{tabular}

TABLE 2. Packing houses building materials and ventilation or cooling systems present in the packaging sector.

\begin{tabular}{|c|c|c|c|c|c|c|c|}
\hline \multirow[b]{2}{*}{$\begin{array}{l}\text { Packing } \\
\text { house }\end{array}$} & \multicolumn{4}{|c|}{ Sealing Walls } & \multicolumn{2}{|l|}{ Roof } & \multirow[b]{2}{*}{$\begin{array}{l}\text { Mechanical } \\
\text { systems of } \\
\text { conditioning }\end{array}$} \\
\hline & Block & $\begin{array}{l}\text { Coating } \\
\text { mortar }\end{array}$ & $\begin{array}{l}\text { External } \\
\text { paint/ new } \\
\text { (n), old (o) }\end{array}$ & $\begin{array}{l}\text { Internal roof } \\
\text { / height (m) }\end{array}$ & Tile type/ color & Linir & \\
\hline ST & Ceramic & $\begin{array}{l}\text { Internal / } \\
\text { external }\end{array}$ & $\begin{array}{c}\text { Yellow (n) } \\
\alpha=0.30\end{array}$ & 3.5 & Zinc-metal & No & $\begin{array}{l}6 \text { fans of } \\
200 W\end{array}$ \\
\hline FS & Concrete & Internal & $\begin{array}{l}\text { White (n) } \\
\alpha=0.20\end{array}$ & 4.0 & $\begin{array}{c}\text { Asbestos } \\
\text { cement - Grey }\end{array}$ & No & $\begin{array}{c}2 \text { Evaporative } \\
\text { coolers }\end{array}$ \\
\hline SF & Concrete & $\begin{array}{c}\text { Internal / } \\
\text { external }\end{array}$ & $\begin{array}{l}\text { White (n) } \\
\alpha=0.20\end{array}$ & 3.2 & $\begin{array}{c}\text { Asbestos } \\
\text { cement - Grey }\end{array}$ & PVC & $\begin{array}{c}4 \text { Evaporative } \\
\text { coolers }\end{array}$ \\
\hline
\end{tabular}

\section{Microclimate monitoring}

For the characterization of the thermal environment, the air temperature (airT; ${ }^{\circ} \mathrm{C}$ ) and air relative humidity $(\mathrm{RH}, \%)$ were collected, using data loggers HOBO, H12 model (Onset, Bournemouth, England) in twenty points distributed in the selection sector of the facilities arranged at one meter of height, in a grid of $3 \times 3$ meters. In three of this points, black globes collecting temperature data of the globe center $\left({ }^{\circ} \mathrm{C}\right)(\mathrm{d}=15 \mathrm{~cm}, \varepsilon=0.9)$ were distributed as follows: a sensor in the center and two sensors at the ends of each wall in the middle of the facility and air speed, measured with a Termoanemometer, TAD 500 model (Instrutherm, São Paulo, Brazil).

The data were collected in fifteen-minute intervals for twenty days at each facility, in two periods, winter 2014 and summer 2015.

The hourly averages of airT and external RH were obtained by the weather station of the Agricultural Timbaúba company, Petrolina-PE (Latitude: $09^{\circ} 13$ 'S, Longitude: $40^{\circ} 29^{\prime} \mathrm{W}$ ), the same monitoring periods were used as reference.

The evaluated parameters were the hourly averages of airT $\left({ }^{\circ} \mathrm{C}\right)$ and $\mathrm{RH}(\%)$ for the monitoring period, and radiant thermal load - RTL (W/m²), calculated according to the [eq.(1)] (BARNABE, 2015), and ART - average radiant temperature; $V v$ - wind speed $\left(\mathrm{m} . \mathrm{s}^{-1}\right) ; \mathrm{Tg}$, black globe temperature $(\mathrm{K})$; $T d b$, dry bulb temperature $(\mathrm{K})$, Stefan-Boltzmann constant of 5.67. $10^{-8} \mathrm{~W} \cdot \mathrm{m}^{-2} \cdot \mathrm{K}^{-4}$.

$$
\begin{aligned}
& \mathrm{RTL}=\tau(\mathrm{ART}) \\
& \mathrm{ART}=100\left\{\left[2.51(\mathrm{VV})^{0,5}(\mathrm{Tg}-\mathrm{Tdb})+(\mathrm{Tg} / 100)^{4}\right]^{0,25}\right\}
\end{aligned}
$$

\section{Constructive housing}

For the analysis of the housing materials - wall coverings - the thermal transmittance of components was considered - $\mathrm{U}\left(\mathrm{W} / \mathrm{m}^{2}{ }^{\circ} \mathrm{K}\right)$. The values were based on the NBR 15220-2 (ABNT, 2005) and are shown in Table 3. 
TABLE 3. Thermal transmittance of walls and roofs of the evaluated packing houses.

\begin{tabular}{ccc}
\hline & Wall $\mathrm{U}\left(\mathrm{W} / \mathrm{m}^{2}{ }^{\circ} \mathrm{K}\right)$ & Roofs $\mathrm{U}\left(\mathrm{W} / \mathrm{m}^{2}{ }^{\circ} \mathrm{K}\right)$ \\
\hline ST & 2.43 & $5.307(\mathrm{CANEPPELE}$ et al., 2013$)$ \\
FS & 2.87 & 4.55 \\
SF & 2.78 & 1.76 (with air chamber and PVC lining) \\
\hline
\end{tabular}

The NBR 15220-3 (ABNT, 2005-3) classifies the thermal insulation and the performance levels of building components with a view at thermal transmittance - U. The information and application for the Zone 7 - DFHI type, according to ABNT (2005-3) are shown in Table 4.

TABLE 4. Thermal transmittance of walls and roofs, classification based on insulation and level of thermal performance, according to ABNT (2005).

\begin{tabular}{|c|c|c|c|c|c|}
\hline $\begin{array}{l}\text { Thermal } \\
\text { insulation }\end{array}$ & $\begin{array}{l}\text { Walls } \\
\mathrm{U}\left(\mathrm{W} / \mathrm{m}^{2}{ }^{\circ} \mathrm{K}\right)\end{array}$ & $\begin{array}{l}\text { Roofs } \\
\mathrm{U}\left(\mathrm{W} / \mathrm{m}^{2}{ }^{\circ} \mathrm{K}\right)\end{array}$ & $\begin{array}{l}\text { Thermal } \\
\text { performance } \\
\text { level } \\
\text { (Zones } 1 \text { to } 7 \text { ) }\end{array}$ & $\begin{array}{l}\text { Roofs } \\
\mathrm{U}\left(\mathrm{W} / \mathrm{m}^{2}{ }^{\circ} \mathrm{K}\right)\end{array}$ & $\begin{array}{l}\text { External walls } \\
\mathrm{U}\left(\mathrm{W} / \mathrm{m}^{2}{ }^{\circ} \mathrm{K}\right) \\
\text { recommendation }\end{array}$ \\
\hline Light & $\leq 3.00$ & $\leq 2.00$ & Minimum & $\leq 2.30$ & \multirow{3}{*}{$\begin{array}{l}\leq 3.60, \text { for } \\
\alpha \leq 0.60\end{array}$} \\
\hline Light reflector & $\leq 3.60$ & $\leq 2.30 \mathrm{VF}^{*}$ & Intermediate & $\leq 1.50$ & \\
\hline Heavy & $\leq 2.20$ & $\leq 2.00$ & Enough & $\leq 1.00$ & \\
\hline
\end{tabular}

*FV - ventilation factor, defined according to the size of the openings.

Considering the width of the eaves, ceilings and the presence of vegetation to calculate the angles of sunscreens, we scaled the number of sunshine hours on the walls of the housing of the evaluated sectors provided in Table 5.

TABLE 5. Number of hours of sunlight incidence on the packing houses walls, in the winter and summer.

\begin{tabular}{|c|c|c|c|c|c|c|}
\hline \multirow[b]{2}{*}{ Packing } & \multirow[b]{2}{*}{ Season } & \multicolumn{4}{|c|}{ Hours } & \multirow{2}{*}{ Observation } \\
\hline & & East & West & North & South & \\
\hline \multirow{2}{*}{ SF } & Winter & 0 & 0 & 0 & 0 & \multirow{2}{*}{$\begin{array}{l}\text { There are no walls that border with the } \\
\text { external environment. }\end{array}$} \\
\hline & Summer & 0 & 0 & 0 & 0 & \\
\hline \multirow[b]{2}{*}{ ST } & Winter & 2.5 & 7 & 0 & 0 & \multirow{2}{*}{$\begin{array}{l}\text { The selection and packing sector is } \\
\text { contiguous to the shipping sector, which is } \\
\text { exposed to the west face of the facility. }\end{array}$} \\
\hline & Summer & 2.5 & 0 & 0 & 8 & \\
\hline \multirow[b]{2}{*}{ FS } & Winter & 5.5 & 0 & 0 & 0 & \multirow{2}{*}{$\begin{array}{l}\text { The facility on the east side receives the } \\
\text { radiation, and the selection sector is } \\
\text { divided by masonry by the shipping sector. }\end{array}$} \\
\hline & Summer & 5 & 0 & 0 & 0 & \\
\hline
\end{tabular}

\section{RESULTS AND DISCUSSION}

\section{Analysis in the winter period}

The temperatures closer to the ones recommended for the selection and packing area of table grape in the packing house (of $20^{\circ} \mathrm{C}$, according to the recommendations of SOARES \& LEÃO (2009) occurred between 5 and 6 am, in the winter (Figure 2) as can be seen in the table 6 . There is a thermal difference between the interior of the facility and the weather station about $3{ }^{\circ} \mathrm{C}$ in the minimum hour, indicating the need of using cooling equipment for the adjustment of the thermal environment, beyond of a better design of packing house structure in projective terms and the use of building materials. 
TABLE 6. Minimum and maximum temperatures of internal and external air in the packing houses during the winter.

\begin{tabular}{ccccc}
\hline Packings & Internal Air Temperature ${ }^{\circ} \mathrm{C}$ & \multicolumn{3}{c}{ External Air Temperature ${ }^{\circ} \mathrm{C}$} \\
& $6 \mathrm{am}$ & $3 \mathrm{pm}$ & $6 \mathrm{am}$ & $3 \mathrm{pm}$ \\
\hline ST & $21.9^{\circ} \mathrm{C}$ & $29.0^{\circ} \mathrm{C}$ & $19^{\circ} \mathrm{C}$ & $29.9^{\circ} \mathrm{C}$ \\
FS & $23.5^{\circ} \mathrm{C}$ & $30.3^{\circ} \mathrm{C}$ & $21.3^{\circ} \mathrm{C}$ & $31.6^{\circ} \mathrm{C}$ \\
SF & $21^{\circ} \mathrm{C}$ & $25.6^{\circ} \mathrm{C}$ & $18.4^{\circ} \mathrm{C}$ & $29.3^{\circ} \mathrm{C}$ \\
\hline
\end{tabular}

High temperatures in the selection and packaging of grapes can promote an accelerated blackening of the stems, rot, reducing firmness, increasing the shattering index (BRACKMANN et al., 2000).

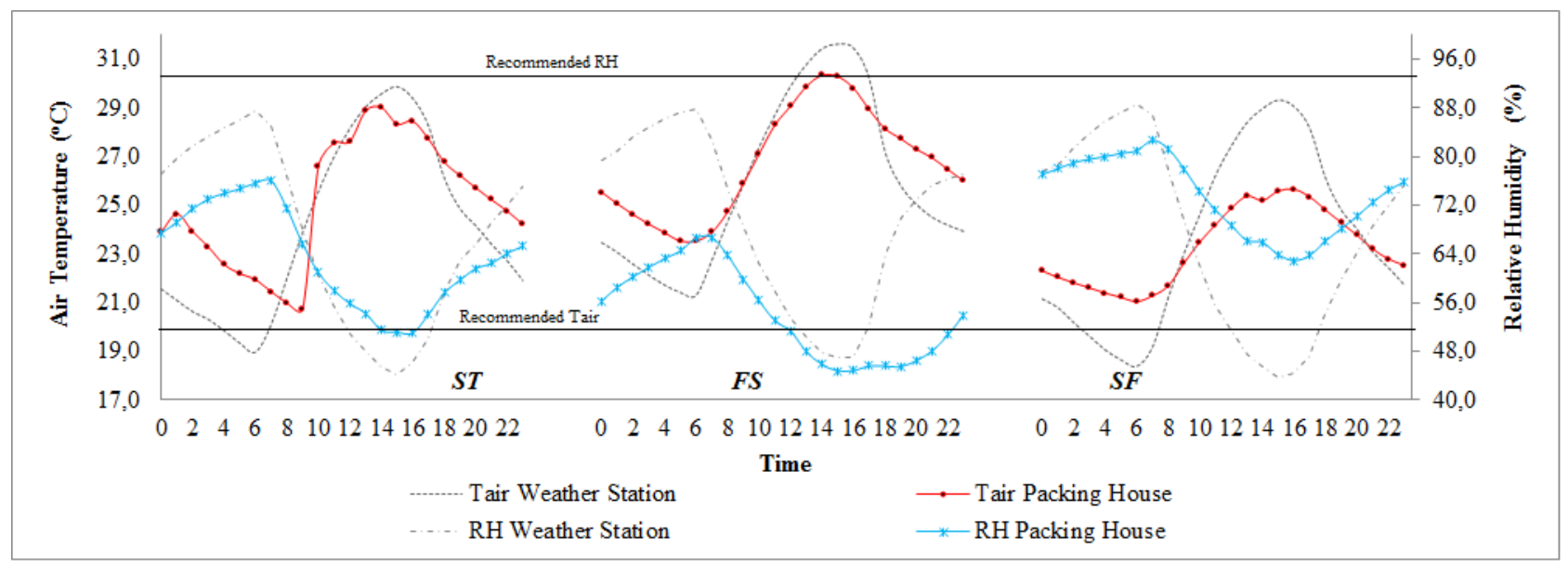

FIGURE 2. Hourly average of temperature and relative humidity obtained in the packaging sector in the packing houses and in the weather station Timbaúba, Petrolina-PE (Latitude: $09^{\circ} 13^{\prime}$ S, Longitude: $\left.40^{\circ} 29^{\prime} \mathrm{W}\right)$. Data obtained during winter 2014.

An exception occurred in the ST packing house where lower temperatures $\left(27.6^{\circ} \mathrm{C}\right)$ occurred from 8 am to 9 am (Figure 2) due to the beginning of the selection activities and late packaging at $10 \mathrm{am}$, with activation of fans, opening of gates and therefore air exchanges with the external environment and floor washing.

The FS packing house showed higher temperatures in the winter (Figure 2), due mainly to the use of building material of low thermal sealing resistance - concrete block walls with mortar of ceramic finishing only inside the facility and white paint on the outside (Table 3 and 4). Thus, there is low thermal difference between the external and internal environment and low thermal damping. The use of sealing materials with thermal properties such as low absorptance, high reflectance, low transmittance and high thermal inertia would be the most suitable for warm climates, increasing day time with milder temperatures in the facility and adjusting it to grape processing activity.

Studies show the importance of proper selection of materials to be used in the packing as reported by SILVA et.al. (2015), that for masonry should be chosen high caloric capacity materials, such as solid bricks or drilled blocks, which promotes the damping of the external temperature variations. Studies also show that the white color of the masonry external surface and roof reduce the internal air temperature by up to $3^{\circ} \mathrm{C}$ at the hottest times of the day (PASSINI et al., 2013).

The lowest temperature observed between the packing houses in winter was from $\mathrm{SF}\left(21^{\circ} \mathrm{C}\right)$ (Figure 2), this occurred because the installation has conditioning, besides the adequate construction techniques such as height ceilings, eaves, use of PVC lining, as well as the selection sector masonry did not receive direct radiation (Table 3, 4 and 5) because the sector partitions are around other areas of the facility and its orientation is east-west (Figure 1). 
There was the average time of relative humidity $(\mathrm{RH})$ in grape selection sector of packing houses, in the winter season, where the highest values occurred at 6 am due to the sector washing, and the internal RH values were: 82.7, 76, 66.8\% and external RH: 86.9, 87.5, 85.8\%, respectively for the SF, ST and FS packing houses (Figure 2). The lowest RH occurred at $3 \mathrm{pm}$ in winter where the internal values were 51, 44.8, 63.9\% and the external ones were 44.3, 46.9, 43.8\% for ST, FS and SF, respectively (Figure 2).

The results show that even in times of highest RH (Figure 2), the three packing houses did not reach the $90 \%$ value considered ideal by SOARES; LEAO (2009). All packing houses obtained differentiated RH values, caused by both climatic aspects, since only in the FS data collection period the relative humidity was above the recommended by these authors, and also because of the microclimate, projective differences related to the conditioning systems (Table 3 and 5).

The ST packing, small size, had vegetation and soil cover on the side of the building (Table 3 and 4), reducing the incidence of solar radiation on the walls. This facility had zinc tiled roof that interferes negatively in the facility with $\mathrm{U}=5.43 \mathrm{~W} / \mathrm{m}^{\circ} \mathrm{C}$ and thermal conductivity of $112 \mathrm{~W} / \mathrm{m} . \mathrm{K}$, rapidly transmitting radiation into the internal environment.

The vegetation is an important regulatory component of temperature because it absorbs much more easily the solar radiation that is used in their biological processes through photosynthesis and transpiration PIVETTA (2009), which was observed in the ST packing house.

According to SPECHT et al. (2010); DOEBBER (2010); PERALTA (2006), the reduction of the environment RH is related to the high air temperature and the solar radiation exposition in an external wall. This fact happens gradually, with the increase of air temperature at the beginning and end of the day, with a maximum peak temperature at $3 \mathrm{pm}$.

In the SF packing, there were the highest RH values (Figure 2) due to humidification carried out by conditioners, and their construction, beyond the walls do not receive direct or indirect radiation and are located at the east-west axis.

The FS packing house (Figure 2) showed the lowest hourly average values of RH, probably due the fiber cement tiles without lining, no vegetation around the facility and located at the northsouth axis, with great influence of direct and indirect sunlight.

\section{Analysis for the summer period}

In the summer conditions, the minimum and maximum temperatures and respective external temperatures are shown in table 7.

TABLE 7. Minimum and maximum temperatures of internal and external air in the packing houses during the summer.

\begin{tabular}{ccccc}
\hline Packings & \multicolumn{2}{c}{ Internal Air Temperature ${ }^{\circ} \mathrm{C}$} & \multicolumn{2}{c}{ External Air Temperature ${ }^{\circ} \mathrm{C}$} \\
& $6 \mathrm{am}$ & $3 \mathrm{pm}$ & $6 \mathrm{am}$ & $3 \mathrm{pm}$ \\
ST & $24.8^{\circ} \mathrm{C}$ & $32.7^{\circ} \mathrm{C}$ & $21.8^{\circ} \mathrm{C}$ & $33.5^{\circ} \mathrm{C}$ \\
FS & $24.8^{\circ} \mathrm{C}$ & $30.2^{\circ} \mathrm{C}$ & $20.4^{\circ} \mathrm{C}$ & $32.5^{\circ} \mathrm{C}$ \\
SF & $27.2^{\circ} \mathrm{C}$ & $31.1^{\circ} \mathrm{C}$ & $22^{\circ} \mathrm{C}$ & $33.4^{\circ} \mathrm{C}$ \\
\hline
\end{tabular}

In Figure 3, there is the behavior of ST, SF and SF Packing throughout the day in the internal and external air temperature data and relative humidity in the summer period. (Figure 3 ). 


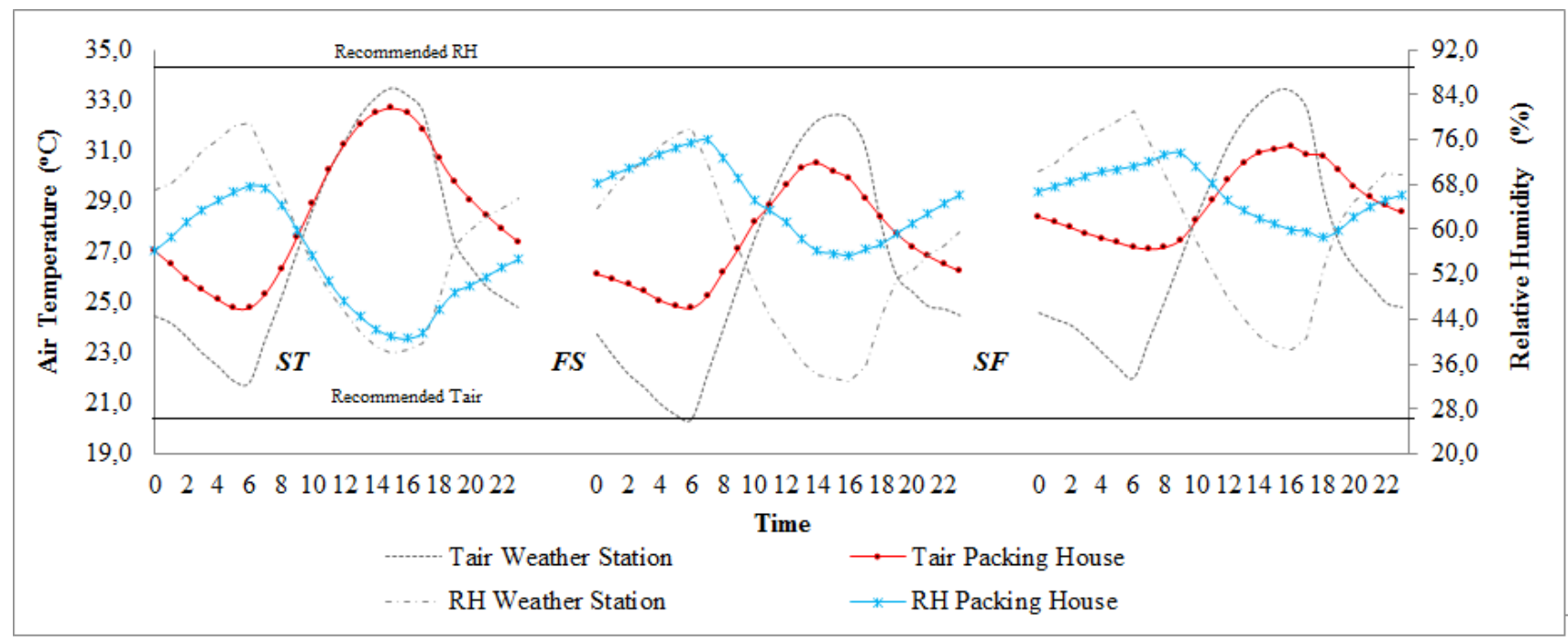

FIGURE 3. Hourly average temperature and relative humidity obtained in the packaging sector of the packing houses and in the weather station Timbaúba, Petrolina-PE (Latitude: $09^{\circ} 13^{\prime}$ S, Longitude: $40^{\circ} 29^{\prime} \mathrm{W}$ ). Data obtained during the summer 2015.

The minimum temperatures in the summer can be observed in the Table 7, paying attention to a thermal variation between the inside of the facilities and the weather station from $3^{\circ}$ to $5.2^{\circ} \mathrm{C}$ at the time of 5 to $6 \mathrm{am}$, reaching higher temperatures of $27.2^{\circ} \mathrm{C}$ in SF (Figure 3). The recommended temperatures for the table grape selection area and packaging in the packing house are $20{ }^{\circ} \mathrm{C}$, according to SOARES \& LEAO recommendations (2009). At this time it is clear the need for conditioning of the studied environments and a possible exchange of building materials.

The higher air temperatures during the summer, occurred at $3 \mathrm{pm}$ in all facilities, highlighting the ST packing that showed average values of the twenty days of analysis of $32.7^{\circ} \mathrm{C}$ for that time, possibly the causes for the ST has obtained temperature values so marked is due to fast thermal transmission promoted by metallic roof (table 3), metal gates and ventilation system that blows hot air from the roof for the inside of the facility.

From $5 \mathrm{pm}$ to $8 \mathrm{pm}$, the ST and SF values were close, with temperatures of $29.1^{\circ} \mathrm{C}$ at $8 \mathrm{pm}$. For the same time, the FS had temperature of $27.2^{\circ} \mathrm{C}$ (Figure 3). The location, orientation, construction materials and constructive techniques such as: ceiling height, block type, coatings and thermal lag of the materials may have contributed to such heating.

According to PERALTA (2006), the roof while absorbs a great amount of radiation also radiates that heat accumulated in the evening. This fact varies according to the thermal characteristics of the materials and most appropriate climate strategies should be used at each location, using conditioners, exhaust fans, and / or evaporative coolers with short periods in the roof.

The data show that no packing, throughout the summer and at all times, reached the air temperature recommended by SOARES \& LEAO (2009) of $20^{\circ} \mathrm{C}$ for the selection and packaging sector. Thus, the overheating of the packing houses may cause problems in postharvest, since studies carried out by BRON et al in 2005, show that the metabolic activity of fruits increases drastically with the increase of storage temperature.

High temperature associated with low relative humidity in the facilities may cause the increase of metabolic activity, associated with the increase of respiratory rate, which is a catabolic process of carbohydrates resulting in the release of $\mathrm{CO}_{2}$ and weight loss (PAULL, 1999), decreasing flesh firmness, acidity, as well as sugar and aroma, which reduces the final fruit quality for consumption (LUNARDI et al., 2004; BRACKMANN et al., 2005; BRACKMANN et al., 2007; FREITAS et al., 2012). 
The higher thermal transmittance of packing occurred due to the roof type, as the metal for the ST packing with $5.3 \mathrm{~W} / \mathrm{m}^{2} \mathrm{~K}$ and fiber cement with PVC lining for the SF packing house of $1.76 \mathrm{~W} / \mathrm{m}^{2} \mathrm{~K}$ as seen in table 3 .

The lining acts as a physical barrier to radiation transmitted by the roof to the interior of the facility, to allow the formation of the air layer with the roof and contribute to the reduction of heat transfer. Studies show that the conditions for thermal comfort in aviaries with the use of lining at the ceilings height reduce the effects of heat stress on birds (ABREU \& ABREU, 2011).

For the summer conditions (Figure 3), at 6 am the highest RH elevation happened with internal values: $72,67.4,76 \%$ and external: $81,79,78.2 \%$ respectively for SF, ST and FS. At 3 pm the lowest summer humidity for the internal environments: 40.9, 55.8, 61\% and external: 37.9, 33.5, $39.2 \%$, the data refer to the ST, FS and SF, respectively.

The hourly average values show that the RH differs in each packing house facility, this difference is due to the types of building materials used in each packing and the use or not of conditioning equipment. Meteorological data show the minimums occurred at 3 and $4 \mathrm{pm}$ with 37.8, 33 and $38.7 \%$ for ST, FS, SF respectively. And the maximums occurred at 6 am, 78, 79, 81\% for ST, FS and SF. A number of factors contributed to the SF obtain better conditions: RH from the weather station shows the highest average humidity, beyond having better constructive characteristics and conditioners, the internal temperature was lower and therefore the average internal values of RH were higher among the three packing.

The roof material is an important material to be considered for the facilities because it receives a large radiation. Thus, the material quality influences in the reduction of thermal energy transmission. A research developed by ROSSETI et al. (2003), in tropical savanna climate (Aw) in the city of Cuiabá, in the summer season, comparing prototype with vegetated roof and prototype covered with conventional fiber cement tile, they found lower air temperature in the premises with vegetated roof, with a difference of $4.7^{\circ} \mathrm{C}$, as the differences observed in this study, at $3 \mathrm{pm}$ the air temperature average between metal roof and fiber cement was $2.5^{\circ} \mathrm{C}$ for the summer.

As can be seen in Figures 2 and 3, in no time and period, the packing did not obtain the RH considered in the storage point for the fruit selection sector of $90 \%$, according to SOARES \& LEAO (2009). Low air humidity inside the packing houses can promote excessive loss of fruit moisture, which can lead to wilting, depreciating the product (NGCOBO et al., 2013).

On the data that were discussed about the three packing houses, buildings do not follow a pattern, where the temperature and humidity recommendations do not fit the winter and summer seasons in these facilities. Other facilities are being built in Brazil, more authorial, taking into account the particular needs than the rules.

In Figure 4, the hourly average values of radiant thermal load (RTL) during winter are shown. In the times from 0 to 6 , the highest values of RTL in FS were observed; probably it may have occurred due to the constructive characteristics, no external coating, roof type, higher sector volume and bad conditioning. 


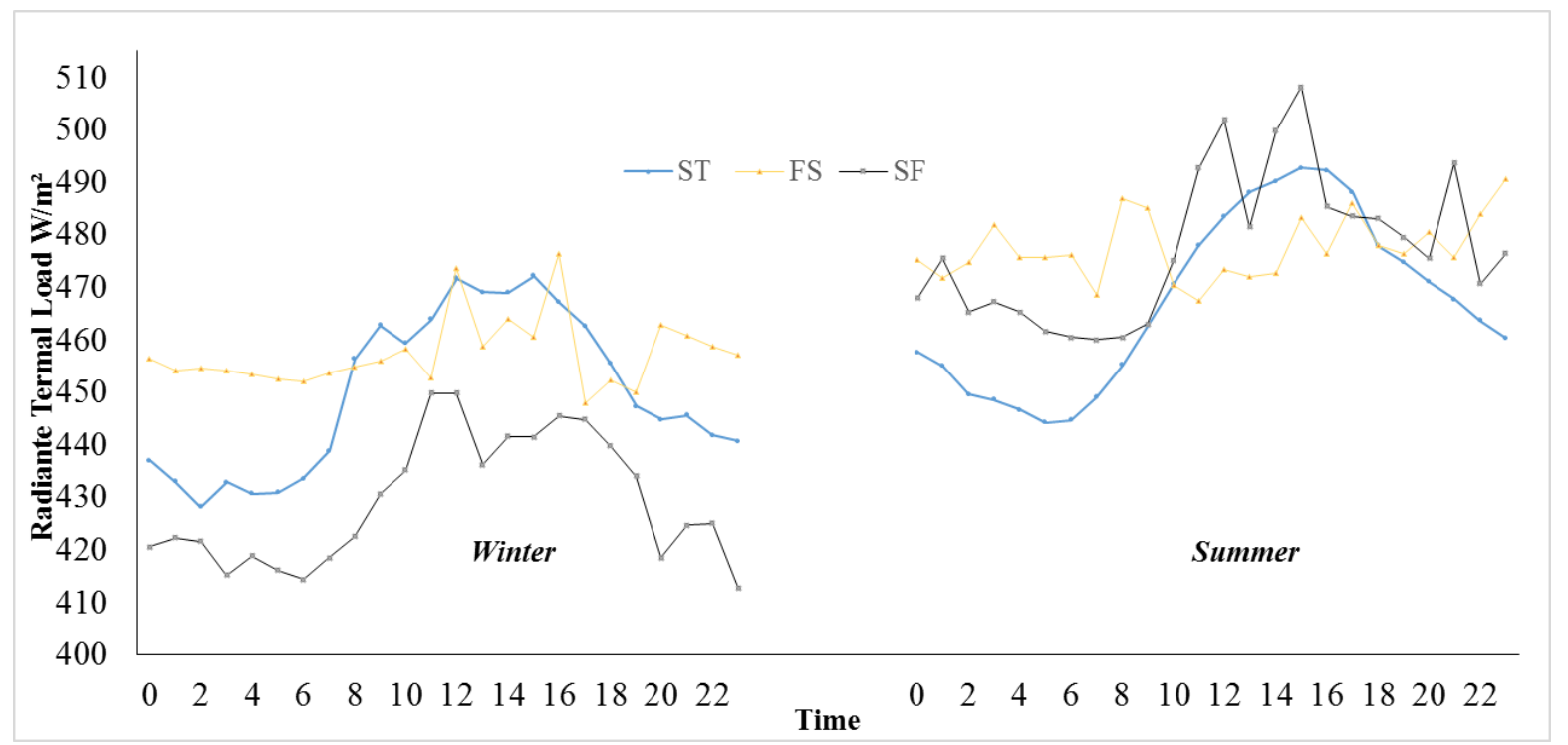

FIGURE 4. Hourly average of radiant thermal load (RTL) in the selection sector of three packing houses during winter and summer.

In the times from 8 am to 10 am, the highest values observed were in the FS and ST packing, $454 \mathrm{~W} / \mathrm{m}^{2}$ and $458 \mathrm{~W} / \mathrm{m}^{2}$ respectively. The lower RTL was from SF with $430 \mathrm{~W} / \mathrm{m}^{2}$, this fact can be attributed to the location disposals that do not receive direct radiation and the use of conditioners.

The higher RTL, in winter, occurred from $1 \mathrm{pm}$ to $3 \mathrm{pm}$, the ST was the one that obtained the highest value (Figure 4), due to probably the use of metal tile, which has a high thermal transmittance. For the $3 \mathrm{pm}$, the RTL values were observed in the packing: $472,460.45$ and 445.36 for ST, FS and SF respectively.

For the summer conditions (Figure 4), the maximum values of RTL occurred at $3 \mathrm{pm}$ with 508, 492.6 and $483.1 \mathrm{~W} / \mathrm{m}^{2}$ of SF, ST and FS packing, respectively. The highest average was observed in SF; because the same was with an overload of fruit to be packaged, thus increased the operating to meet the demand and the facility was undersized for this increase.

At $8 \mathrm{pm}$ the higher RTL was in SF $493.5 \mathrm{~W} / \mathrm{m}^{2}$, the cause probably is due to the thermal transmittance and thermal lag of roof materials and masonry that are overcome, transmitting power to the sector. The cold storage of this facility in the selection sector was disconnected and did not have opening so there was no natural ventilation, thus, another clue that the thermal energy absorbed by the masonry was transferred to the interior more quickly.

The ST packing house (Figure 4) had the lowest value of RTL at night time of $467.6 \mathrm{~W} / \mathrm{m}$ at 8 $\mathrm{pm}$, due to the fact that metal tile has high transmittance, thus in the absence of solar radiation it cools faster because there is a reduction in thermal lag, reducing its influence in the selection and packaging sector in these times. The natural ventilation in this facility and leaked screens in the building were among the factors that helped to get these values.

The solar radiation is $75 \%$ of the total RTL that reaches a facility and it can be reduced shadowing the facility through the use of trees and shrubs or with the use of materials that provide artificial shading (MOURA, 2001).

A study developed by SAMPAIO et al (2011) studying roof materials evaluated the RTL during winter and summer from 8 am to $6 \mathrm{pm}$. In the summer, there was a variation from 406.7 to $479.2 \mathrm{~W} \mathrm{~m}^{-2}$, from 405.0 to $480.5 \mathrm{~W} \mathrm{~m}^{-2}$ and of 406.2 to $518.3 \mathrm{~W} \mathrm{~m}^{-2}$ for ceramic, fiber cement and metal tiles, respectively. The peaks of these data occurred from $12 \mathrm{pm}$ to $4 \mathrm{pm}$. The ceramic and fiber cement tiles had close behaviors and are superior to metal tiles to reduce radiation thermal load, corroborating with the data obtained in this experiment during the summer season (Figure 4) by the roof of the evaluated packing houses, showing better thermal conditions for fiber cement 
tiles, which are the FS and SF roofing material. The metal roof values in the ST range from 428 to $472 \mathrm{~W} \mathrm{~m}^{-2}$ showing the lower maximums in relation to this study.

\section{CONCLUSIONS}

The internal environments of the packing houses studied did not provide adequate conditions in the selection sectors for the grapes, during winter and summer.

There is the need for adequacy of those facilities with conditioners sized correctly and the application of construction materials and techniques that improve the thermal performance.

\section{ACKNOWLEDGEMENTS}

We thank to the FACEPE for the scholarship and to the FAPESB for the financing of this research project.

\section{REFERENCES}

ABNT - ASSOCIAÇÃO BRASILEIRA DE NORMAS TÉCNICAS. NBR 15220-3 - Desempenho térmico de edificações - Parte 3: Zoneamento bioclimático brasileiro e diretrizes construtivas para habitações unifamiliares de interesse social. Rio de Janeiro, 2005.

ABNT - ASSOCIAÇÃO BRASILEIRA DE NORMAS TÉCNICAS. NBR 15220-2 - Desempenho térmico de edificações - Parte 2: Zoneamento bioclimático brasileiro e diretrizes construtivas para habitações unifamiliares de interesse social. Rio de Janeiro, 2005.

ABREU, V. M. N.; ABREU, P. G. Os desafios da ambiência sobre os sistemas de aves no Brasil. Revista Brasileira de Zootecnia, Viçosa, MG, v.40, n. s/n, p.1-14. 2011.

BARNABE, J. M. C.; PANDORFI, H.; ALMEIDA, G. L. P.; GUISELINI, C.; JACOB, A. L. Conforto térmico e desempenho de bezerras Girolando alojadas em abrigos individuais com diferentes coberturas. Revista Brasileira de Engenharia Agrícola e Ambiental, Campina Grande, v.19, n.5, p.481-488. 2015.

BRACKMANN, A.; FREITAS, S. T.; GIEHL, R. F. H.; MELLO, A. M.; ANTES, R. B. O resfriamento rápido e a rápida instalação da atmosfera controlada como substitutos do 1-MCP no armazenamento de maçãs 'Gala'. Revista Brasileira de Fruticultura, Jaboticabal, v.27, n.3, p.379382. 2005.

BRACKMANN, A.; WEBER, A.; FREITAS, S. T.; PINTO, J. A.V. Substituição do 1metilciclopropeno pela instalação rápida das condições de atmosfera controlada em maçãs 'Fuji'.

Revista Brasileira de Armazenamento, Viçosa, MG, v.32, n.s/n, p.38-43. 2007.

CANEPPELE, F. L.; SERAPHIM, O. J.; GABRIEL FILHO, L. R. A.; CREMASCO, C. P.; SAVI, A. F. Gains obtained in hybrid systems of energy generation solar photovoltaic and wind power for rural electrification with the use of fuzzy logic controllers based. Scientific Journal Agricultural Engineering, Pavia, v.2, n.2, p.35-44. 2013.

DOEBBER, A. T. N. Estudo para redução do impacto térmico em paredes de alvenaria: influência das cores e do uso do brise soleil. 2010. 120 f. Monografia (Trabalho de Graduação em Engenharia Civil) Universidade Regional do Noroeste do Estado do Rio Grande do Sul, Injuí, 2010.

FREITAS, S. T.; PEREIRA, E. I. P.; GOMEZ, A. C. S.; BRACKMANN, A.; NICOLOSO, F.; BISOGNIN, D. A. Processing quality of potato tubers produced during autumn and spring and stored at different temperatures. Horticultura Brasileira, Vitória da Conquista, v.30, n.1, p.91-98. 2012.

IBGE - INSTITUTO BRASILEIRO DE GEOGRAFIA E ESTATÍSTICA. Produção agrícola municipal. Rio de Janeiro: IBGE, 2014. Disponível em:

<http://ftp.ibge.gov.br/Producao_Agricola/>>Producao_Agricola_Municipal_[anual]/2012/tabelas_ pdf/tabela04.pdf $>$. Acesso em: 5 fev. 2014. 
LUNARDI, R.; FREITAS, S.T.; BRACKMANN, A.; MELLO, A. M.; ZANATTA, J. F.;

ROMBALDI, C. V. Suculência e solubilização de pectinas de maçãs 'Gala' submetidas a diferentes tempos de resfriamento e aplicação de 1-MCP. Ciência e Agrotecnologia, Lavras, v.28, n.4, p.871877. 2004.

MOURA, D. J. Ambiência na avicultura de corte. In: SILVA, I. J. O. (Ed.). Ambiência na produção de aves em clima tropical. Piracicaba: FUNEP, 2001. p.75-149.

NGCOBO, M.E.K.; DELELE, M. A.; OPARA U. L.; MEYER C. J. Performance of multipackaging for table grapes based on airflow, cooling rates and fruit quality. Journal of Food Engineering, v.116, n.2, p.613-621. 2013.

PASSINI, R.; ARAÚJO, M. A. G.; YASUDA, V. M.; ALMEIDA, E. A. Intervenção ambiental na cobertura e ventilação artificial sobre índices de conforto para aves de corte. Revista Brasileira de Engenharia Agrícola e Ambiental, Campina Grande, v.17, n.3, p.333-338, 2013. Disponível em: <http://www.scielo.br/pdf/rbeaa/v17n3/13.pdf>. Acesso em: 20 jul. 2013.

PAULL, R. Efect of temperature and relative humidity on fresh commodity quality. Postharvest Biology and Technology, Amsterdam, v.15, n.3, p.263-277. 1999.

PERALTA, G., Desempenho térmico de telhas: Análise de monitoramento e normalização específica. 2006. Dissertação (Mestrado) - Escola de Engenharia da São Carlos, Universidade de São Paulo, São Carlos, 2006.

PIVETTA, J. Influência de Elementos Paisagísticos no Desempenho Térmico de Edificação Térrea. 2009. Dissertação (Mestrado em Engenharia de Edificações e Saneamento) - Universidade Estadual de Londrina, Londrina, 2009.

RIBEIRO, T. P.; LIMA, M. A. C. de; SOUZA, S.O.; ARAUJO, J. L. P. Perdas Pós-Colheita em uva de mesa registradas em casas e embalagem e em mercado distribuidor. Revista Caatinga, Mossoró, v.27, n.1, p.67-74. 2014.

ROSSETI, K. A. C.; NOGUEIRA, M. C. J. A.; FRANCO, F. M.; NOGUEIRA, J. S. Análise da interferência da cobertura verde na temperatura e umidade relativa do ar do entorno da edificação Estudo de caso em protótipo no município de Cuiabá, MT. Revista Eletrônica em Gestão, Educação e Tecnologia Ambiental, Santa Maria, v.9, n.9, p.1959-1970. 2013.

SAMPAIO, C. A. P.; CARDOSO, C.O.; SOUZA, G. P. Temperaturas superficiais de telhas e sua relação com o ambiente térmico. Revista Brasileira de Engenharia Agrícola Ambiental, Campina Grande, v.31, n.2, p.230-236. 2011.

SOARES, J. M.; LEÃO, P. C. de S. (Ed.) A vitivinicultura no semiárido brasileiro. Brasília, DF: Embrapa Informação Tecnológica, Vetrolina: Embrapa Semiárido, 2009. 756p.

SPECHT, L. P.; BORGES, P. A.; ZANON, R. V. Análise da transferência de calor em paredes compostas por diferentes materiais. Ambiente Construído, São Paulo, v.10, n.4, p.7-18. 2010.

TEXEIRA, A. H. C.; LIMA, J.M.P.L. Agência de informação da Embrapa. Brasília, DF: Embrapa Informação Tecnológica; Petrolina: Embrapa Semiárido, 2016. 